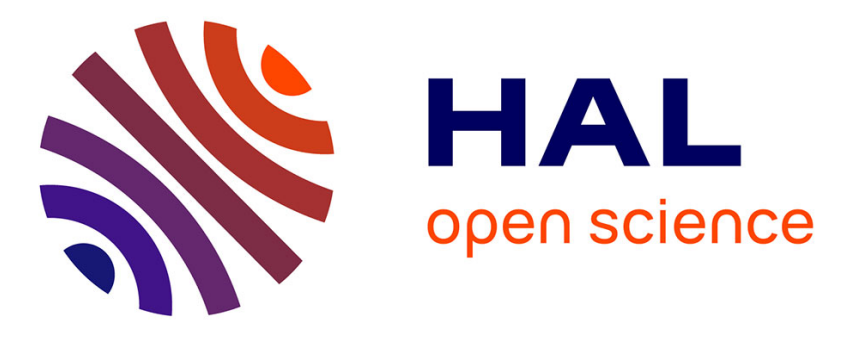

\title{
Serological reactivity and bacterial genotypes in Chlamydia trachomatis urogenital infections in Guadeloupe, French West Indies
}

François-Xavier Weill, Simon Le Hello, Maïthé Clerc, Cédric Scribans, Bertille de Barbeyrac

\section{- To cite this version:}

François-Xavier Weill, Simon Le Hello, Maïthé Clerc, Cédric Scribans, Bertille de Barbeyrac. Serological reactivity and bacterial genotypes in Chlamydia trachomatis urogenital infections in Guadeloupe, French West Indies. Sexually Transmitted Infections, 2010, 86 (2), pp.101-105. 10.1136/sti.2009.037036 . pasteur-02019208

\section{HAL Id: pasteur-02019208}

https://hal-pasteur.archives-ouvertes.fr/pasteur-02019208

Submitted on 11 Mar 2019

HAL is a multi-disciplinary open access archive for the deposit and dissemination of scientific research documents, whether they are published or not. The documents may come from teaching and research institutions in France or abroad, or from public or private research centers.
L'archive ouverte pluridisciplinaire HAL, est destinée au dépôt et à la diffusion de documents scientifiques de niveau recherche, publiés ou non, émanant des établissements d'enseignement et de recherche français ou étrangers, des laboratoires publics ou privés.

\section{(c)(1)}

Distributed under a Creative Commons Attribution| 4.0 International License 
1 Serological reactivity and bacterial genotypes in Chlamydia trachomatis

2 urogenital infections in Guadeloupe, French West Indies

3

4 François-Xavier Weill, MD, $\mathrm{PhD}^{1,3^{*}}$, Simon Le Hello, PharmD, MSc ${ }^{1,3}$, Maithé Clerc ${ }^{2}$,

5 Cédric Scribans, $\mathrm{MSc}^{2}$, and Bertille de Barbeyrac, $\mathrm{PharmD}, \mathrm{PhD}^{12}$

6

$7 \quad{ }^{1}$ Institut Pasteur de la Guadeloupe, Pointe à Pitre, France

8

$9{ }^{2}$ CHU de Bordeaux, Laboratoire de Bactériologie, Centre National de Référence des

10 infections à Chlamydia, Bordeaux, France

11

$12{ }^{3}$ present address:

13 Institut Pasteur, Laboratoire des Bactéries Pathogènes Entériques, Paris, France.

14

15 Corresponding author

16 Laboratoire des Bactéries Pathogènes Entériques, Institut Pasteur, 28 rue du Docteur

17 Roux, 75724 Paris cedex 15, France. Tel: 33-(0)1 456883 45. Fax: 33-(0)1 45688837.

$18 \quad$ E-mail: fxweill@pasteur.fr

19

20 SUMMARY

21

22 Key-words: Chlamydia trachomatis, epidemiology, serology, prevalence, genotyping, 23 Guadeloupe. 
24 Running title: Chlamydia trachomatis in Guadeloupe

\section{KEY MESSAGES}

27

The prevalence of Chlamydia trachomatis urogenital infection was $16.9 \%$ in men and

9.8\% in women in 2000 in Guadeloupe, French West Indies. infections in Guadeloupe, French West Indies, differed from that in mainland France. infected with Chlamydia trachomatis genotype Ia strains.

\section{STATEMENT}

\section{COMPETING INTEREST}

None declared. 


\section{ABSTRACT}

Objectives: To determine the prevalence and genotypes of Chlamydia trachomatis urogenital infection in Guadeloupe, French West Indies. To compare C. trachomatis direct detection to serological testing.

Methods: From March to November 2000, 971 consecutive patients (888 women and 83 men) who had been referred to clinical laboratory of the Institut Pasteur de la Guadeloupe for routine testing for genital infection, were recruited. Samples were subjected to a nucleic acid amplification assay (AMP CT, Gen-Probe). Genotypes were determined by ompl PCR-RFLP analysis. Serological testing was carried out with the commercially available peptide-based ELISA assay (SERO-CT IgG/IgA, Savyon/BMD).

Results: Positive AMP CT test results were obtained for $102(10.5 \%)$ of the 971 samples. The prevalence of infection was $16.9 \%$ in men and $9.8 \%$ in women. The most common genotypes were E (34.3\%), F (23.9\%), Da (13.4\%), I (9\%), and Ia (7.5\%). No relationship was found between genogroups and age, sex or clinical symptoms. With AMP CT used as a reference, the sensitivity, specificity, positive, and negative predictive values of SERO-CT were $81.1 \%, 56 \%, 34.5 \%$ and $91.2 \%$, respectively, for IgG and $55.4 \%, 76.8 \%, 59.4 \%$, and $85.8 \%$, respectively, for IgA. IgG seroprevalence rates were very low $(1 / 5,20 \%)$ in patients infected with genotype Ia strains.

Conclusions: The prevalence found in Guadeloupe did not differ not significantly from that which was found in mainland France. The genotypes Da, F, I, and Ia were more prevalent in Guadeloupe; however, the SERO-CT assay was unable to detect serum antibodies in $80 \%$ of the patients infected with genotype Ia strains. 


\section{INTRODUCTION}

Chlamydia trachomatis is considered to be the most common bacterial cause of sexually transmitted infections (STIs) worldwide. It is currently classified into 19 different serovars on the basis of immunogenic epitope analysis of the major outer membrane protein (MOMP). Serovars D to $\mathrm{K}$, and related variants, Da, Ia, and Ga, are generally found to be associated with urogenital infections. ${ }^{1,2}$ Over the last two decades, genotyping based on the ompl gene, encoding MOMP, has become a convenient alternative to the laborious serotyping method. The single-copy ompl gene displays extensive sequence variations in four regions (VS1-VS4), interspersed with five regions of conserved sequence. The diversity of the DNA can be analyzed by restriction fragment length (RFLP) analysis and/or by sequencing of the PCR-amplified ompl gene. ${ }^{1-11}$ Genotyping was originally carried out on cell cultures, but direct genotyping of clinical specimens is now performed by sensitive nested PCR of the ompl gene. ${ }^{12}$ Phylogenetic analysis of ompl subdivides strains into three distinct genogroups : B (serovars B, Ba, D, Da, E, L1 and L2), intermediate (serovars F, G, and Ga), and C (serovars A, C, H, I, Ia, J, K, and L3). ${ }^{1,2}$

In Guadeloupe, French West Indies, there is no data in the literature concerning C. trachomatis urogenital infection. In mainland France, commercially available PCR methods have showed that the prevalence of such infection in symptomatic populations was $8-10.2 \%$ in women and $16.4 \%$ in men (1994-1998). ${ }^{13,14}$ In the Caribbean region, the prevalence ranges from $5.4 \%$ to $21 \%$ in asymptomatic women from Curaçao, Barbados, and Trinidad, to 55\% in STI clinic patients from Jamaica. ${ }^{15-19}$ Despite the use of different methods and populations, which made the results difficult to compare, these 
studies provide useful data to national health authorities. A piece of valuable information that has not yet been reported in the Caribbean region are the genotypes or serovars of circulating C. trachomatis strains.

We report here the first study on $C$. trachomatis urogenital infection in Guadeloupe. We established the prevalence of this infection by carrying out nucleic acid amplification tests (NAATs) on a population of 971 consecutive patients referred for routine testing for urogenital infection, and determined the genotypes by PCR-RFLP. We searched for relationships between genogroups and particular demographic, clinical, serological, and microbiological characteristics of the infected population.

\section{MATERIALS AND METHODS}

\section{Study population}

Guadeloupe is an overseas French département covering $1705 \mathrm{~km}^{2}$ and located in the Caribbean region. The archipelago had a total population of 422,000 inhabitants (1999 census data).

The selected population consisted of 971 consecutive patients (888 women and 83 men), who were referred to the clinical laboratory of the Institut Pasteur de la Guadeloupe, Pointe à Pitre, Guadeloupe, by general practitioners, dermatologists or gynaecologists during the period from March to November 2000 for routine testing for urogenital infection. All the specimens were collected and all assays other than genotyping were carried out in the laboratory.

Data, including demographic characteristics such as age and sex, clinical 
symptoms and results of all microbiological investigations were recorded for two subsets of patients. The first subset was comprised of patients with a positive NAAT $(n=102)$.

The second subset comprised of those with an available serological test $(n=333)$, was classified as follows: one CT+ group ( $n=74$; median age: $24.6 \pm 7.4$ years; range: $13-44)$ comprised of patients, 65 of which were women and 9 of which were men, with AMP CT-positive assays; and one CT- group ( $\mathrm{n}=259$; median age: $29.2 \pm 9.9$ years; range: 14 70) comprised of 238 women and 21 men. Ethical approval was not required under local law for this study due to its retrospective design and use of data obtained through routine testing.

\section{C. trachomatis nucleic acid detection} trachomatis assay (AMP CT; Gen-Probe, San Diego, USA). This NAAT targets a specific $23 \mathrm{~S}$ rRNA of $C$. trachomatis in a transcription-mediated amplification and hybridisation protection assay. Male urethral $(n=72)$ and female endocervical $(n=867)$ swabs or first-void urine specimens from men $(n=11)$ or women $(n=21)$ were collected and tested according to the manufacturer's instructions.

\section{C. trachomatis antibody detection}

C. trachomatis antibody status was determined on 333 sera from 333 patients with the SERO-CT IgG/IgA test (Savyon/BMD, Marne-La-Vallée, France), according to 
144 the manufacturer's instructions. This microtiter-based ELISA uses a mixture of species145 specific peptides from the C. trachomatis MOMP for the detection of specific IgG and 146 IgA antibody. Samples with index values (OD sample/OD negative control x 2) $\leq 1.1$ 147 were considered negative, whereas those with index values $>1.1$ were considered 148 positive.

149

150

151

Of the 100 AMP CT-positive non-urine specimens, stored in a Gen-Probe transport tube at $-70^{\circ} \mathrm{C}, 99$ were transported frozen, overnight, to the French National Reference Centre for C. trachomatis. Samples were diluted 1/10 with lysis buffer and nested PCR analyses were performed by using primers NLO and NRO in the first step and PCTM3 and SERO2A in the second step, as described previously. ${ }^{5,6}$ The RFLP analysis of nested PCR products was carried out by using AluI, HpaII-EcoRI-HinfI, CfoI, DdeI, and FokI, as described previously. ${ }^{5,6}$

\section{Statistical analysis}

Univariate comparisons were based on the Pearson's chi-squared statistic or twotailed Fisher's exact tests for categorical variables, and on Student's t tests or analysis of variance for continuous variables. Analyses were performed with Stat software (Stata 7.0; Stata, College Station, USA). A p value of 0.05 was considered statistically significant. 


\section{RESULTS}

170

\section{C. trachomatis prevalence and characteristics of the infected population}

172

Positive results in the NAAT were obtained for 102 of the 971 samples (10.5\%).

women. The mean age of infected men and women was $29.4 \pm 6.9$ years (range 20-44)

and 24.4 \pm 7.2 years (range 13-44), respectively. Clinical symptoms were present in $89.3 \%(75 / 84)$ of infected women and in $92.9 \%(13 / 14)$ of infected men. The prevalence in women of co-infection with HIV, Neisseria gonorrhoeae, Trichomonas vaginalis and Candida albicans was 5.9\% (5/84), 2.3\% (2/87), 3.4\% (3/87), 19.5\% (17/87), and 5.7\%

\section{Distribution of the C. trachomatis genotypes} samples. The distribution of the genotypes is shown in Table 1. The genotypes E (34.3\%), F (23.9\%), Da (13.4\%), I (9\%), and Ia (7.5\%) were the most common. The genotypes were evenly distributed over the study period (data not shown). Due to the small number of non-E and non-F genotypes, the genotypes were grouped together into 
the $\mathrm{B}$, intermediate, and $\mathrm{C}$ genogroups for further analysis. ${ }^{1}$

\section{Association of genogroups with demographic characteristics and clinical signs}

Table 2 shows the association between demographic characteristics, clinical signs, laboratory data and genogroup. No relationships were found between genogroup and age, sex, clinical symptoms or other associated genital infections other than $N$. gonorrhoeae and the $\mathrm{C}$ genogroup ( $\mathrm{p}=0.005)$. These co-infections (two caused by Ia genotype strains and two by I genotype strains) occurred between July and September.

\section{Relationships between chlamydial infection and serological data}

We evaluated the potential usefulness of serological testing, by analysing a subpopulation of 333 patients with an available serological test result with the commercially available peptide-based ELISA, SERO-CT IgG/IgA. A comparison of the serological results with the results of the NAAT is shown in Table 3. The $\operatorname{IgG}$ and $\operatorname{IgA}$ seroprevalence rates and the mean $\operatorname{IgG}$ and $\operatorname{IgA}$ ratios in the $\mathrm{CT}+$ group were significantly higher than those in the CT-group.

The sensitivity of SERO-CT for antibody detection (using the NAAT as the reference) was $81.1 \%$ for $\operatorname{IgG}$ and $55.4 \%$ for $\operatorname{IgA}$. The specificity of detection was $56 \%$ for $\operatorname{IgG}$ and $76.8 \%$ for $\operatorname{IgA}$. The specificity was higher $(81.5 \%)$ for tests for the simultaneous presence of $\operatorname{IgG}$ and $\operatorname{IgA}$. Positive predictive values (PPV) were $34.5 \%$ for IgG and $59.4 \%$ for $\operatorname{IgA}$ and negative predictive values (NPV) were $91.2 \%$ for $\operatorname{IgG}$ and $85.8 \%$ for $\operatorname{IgA}$. IgG antibodies were found in $55.6 \%(35 / 63)$ of patients suffering from 
215 lower abdominal pain. They were found in $81.2 \%(13 / 16)$ in such patients in the CT+ 216 group and $46.8 \%$ (22/47) of such patients in the CT-group; whereas the occurrence of

217 abdominal pain was similar in the two groups: $22.2 \%(16 / 72)$ and $19.1 \%(47 / 246)$, 218 respectively.

219

220 Relationships between genogroup and serological results

221

222

223

224

Serological results were available for 46 of the 67 patients whose strains were genotyped. Table 4 shows IgA and IgA seroprevalence rates as a function of genogroup. Statistically significant higher IgG seroprevalence rates were found in patients infected with genotypes of the intermediate (100\%) and B (92.3\%) genogroups than in those infected with genotypes of the $\mathrm{C}$ genogroup (40\%). Five of the $10 \mathrm{C}$ genogroup strains were of genotype I and the other five were of genotype $\operatorname{Ia}$ IgG was detected in $60 \%$ (3/5) of patients infected with strains of genotype I but in only $20 \%$ (1/5) of patients infected with strains of genotype Ia. 


\section{DISCUSSION}

232

We found the prevalence of $C$. trachomatis urogenital infection to be $10.7 \%$ ( $10 \%$ in women and $18.1 \%$ in men) in our study population. This prevalence was lower than those observed in symptomatic patients from the Caribbean region but did not differ significantly from that of mainland France.

The failure rate (33\%) for determination of genotypes by nested ompl PCR on clinical samples in this study was higher than generally reported $(<20 \%) .{ }^{10,20,21}$ There may be several reasons for this. It is more difficult to amplify the $1.2 \mathrm{~kb}$ ompl gene, which is present as a single copy in the bacterium, than the smaller rRNAs present in many thousands of copies. High failure rates are therefore likely for samples with small numbers of micro-organisms or samples containing small number of infected cells. This may account for the higher failure rate in men $(50 \%)$ than in women $(30.2 \%)$, due to milder urethral scraping in men. Other hypothesis are the lack of a DNA extraction procedure before PCR (Vanduynhoven et al. reported a nested PCR failure rate of $22.9 \%$, which decreased to $4.9 \%$ following the use of DNA extraction methods) and the quality of the DNA matrix stored in the Gen-Probe transport medium, which was developed for the stabilisation of RNA molecules. ${ }^{1}$

This study is the first to describe the $C$. trachomatis genotypes circulating in Guadeloupe and in the Caribbean region. The two most prevalent genotypes in Guadeloupe, E and F, have also been reported to be the most prevalent around the world. $^{9,11,20,22}$ However, the distribution of some other genotypes differed considerably from that in mainland France: in particular, genotypes Da (13.4\% vs 4.5\%), F (23.8\% vs $13.5 \%)$, I (9\% vs $3.5 \%)$ and Ia $(7.4 \%$ vs $0.3 \%)$ were more prevalent, whereas genotypes 
D (5.9\% vs $11.2 \%), \mathrm{G}(3 \%$ vs $11.8 \%), \mathrm{H}(0 \%$ vs $5.1 \%)$, and $\mathrm{K}(0 \%$ vs $5.1 \%)$ were less

256 prevalent. ${ }^{23}$ Genotype Da infections have rarely been described since the first 257 description of this serovar in 1991. ${ }^{24}$ No Da genotypes were found among the 507 ompl 258 sequences obtained for samples from a large US nationwide study conducted between 2591995 and $1997 .{ }^{9}$ A genotyping study by PCR-RFLP $(C f o \mathrm{I})$ in 2001 in Cameroon found 260 a prevalence of the Da genotype of 8.6\% (3/35), whereas in Senegal in 1996-1997, omp1 sequencing revealed a prevalence of D/Da genotypes of $19 \%(4 / 21){ }^{6,11}$ The D/Da strains belong to two distinct phylogenetic lineages. ${ }^{8}$ The Da strains from each lineage have a specific single nucleotide polymorphism (SNP) within ompl resulting in the loss of a $C f o$ I restriction site and in amino acid substitution alanine to threonine at position $311 / 312$ modifying the epitope recognised by the monoclonal antibodies used for the serotyping of group D strains. ${ }^{7,8}$ BLAST analysis can group ompl sequences into the appropriate lineage, but it is necessary to identify the SNP encoding the Ala311/312Thr substitution precisely for Da assignment. This may explain why it is more difficult to detect Da variants by ompl sequencing than by serotyping or PCR-RFLP, leading to possible underestimation. The PCR-RFLP profiles obtained with the Da and D strains from Guadeloupe were similar to those predicted from the ompl sequences of Da/TW448 (first lineage), and D1 or D2 group (second lineage) strains, respectively.

The serovar variant Ia was described in 1991, following a study of 41 genital isolates isolated worldwide, in which Ia isolates were much more frequent than I isolates (41 vs 9). ${ }^{24}$ In the United States, a high prevalence (14\%) of genotype Ia was found during the 1995-1997 study. ${ }^{9}$ Other studies in the US found that infection with serovar Ia was significantly associated with being black. ${ }^{25,}{ }^{26}$ In a study carried out in 1994 in the Netherlands, male patients from Suriname were significantly more frequently 
infected with genotype Ia strains than were men from the Netherlands, and women from Suriname were more frequently infected with genogroup $\mathrm{C}$ strains than were women from the Netherlands. ${ }^{1}$ In Africa, one study conducted in Senegal, found a genotype Ia prevalence of $4.8 \%(1 / 21) .{ }^{11}$ In Asia, one studied reported a prevalence of genotype Ia infection of $6.6 \%$ in pregnant women in Thailand, whereas another study reported a significant increase in the prevalence of genotype I strains (Ia not differentiated from I) in Japan between the mid 1990s $(1 / 41,2.1 \%)$ and $2003-2005(10 / 81,12.3 \%) .{ }^{9,}{ }^{27}$ In Guadeloupe, a large proportion of the population is Black and of African descent (about $80 \%$ ) and about $15 \%$ of the population is "Indian" and of Asian descent. That may explain why genotypes I (9\%) and Ia (7.5\%) were well represented.

Serological results and direct evidence of infection have not been found to correlate in many reports, even with an ELISA using specific C. trachomatis MOMP peptides. ${ }^{28,} 29$ This has been partially attributed to the antibody kinetics (i.e., the lag period between being infected and the antibody response and the persistence of antibodies after a resolved infection). Rabenau et al. reported a lower specificity (37.3\%) and a much lower PPV $(<20 \%)$ for IgG detection with SERO-CT than for detection with NAAT. ${ }^{29}$ However, a high NPV (96.4\%) was found to be useful for identifying patients at high risk in whom $C$. trachomatis infection is unlikely to play a role. SEROCT was reported to outperform PCR for $\mathrm{IgG}$ detection in another study (specificity of $69 \%$ and PPV of 50\%). ${ }^{28} \mathrm{We}$ also found that this assay performed well for $\operatorname{IgG}$ and $\operatorname{IgA}$ detection in comparison with AMP CT. Our results, however, could be affected by patient selection bias as the analyses were done on a subpopulation selected based on the basis on available serology. The requests for serology might indicate a higher risk of $C$. trachomatis infection, in particular upper genital tract infection or recurrent infections. 
Indeed, the prevalence of this infection was found to be $21.5 \%(65 / 333)$ in the 304 subpopulation vs $10.7 \%$ within the whole population. For optimal serological results, the 305 selection or preparation of the microbial antigen is important. In a follow-up study, the 306 SERO-CT gave false-negative results and the authors suggested that this test might not 307 be suitable for all serovars. ${ }^{30}$ We show here that SERO-CT detected no antibody 308 response in $6 / 10$ patients infected with strains of the $C$ genogroup, particularly genotype

309 Ia strains. However, further studies involving more cases are necessary to confirm this 310 finding. The exact composition of the SERO-CT antigen mixture has not been made 311 publicly available, but it seems likely than no Ia-derived peptide was included. 312 Therefore, in seroepidemiological studies using such high-specificity ELISA-based 313 assays, it is essential to establish, before beginning the study, that the ELISAs used are 314 capable of detecting an antibody response in patients infected with the various 315 circulating genotypes.

\section{AUTHOR CONTRIBUTIONS} manuscript.

\section{WORD COUNT}

326 Abstract (254), text (2567), number of figures (0) and tables (4) 
1. van Duynhoven YT, Ossewaarde JM, Derksen-Nawrocki RP, et al. Chlamydia trachomatis genotypes: correlation with clinical manifestations of infection and patients's characteristics. Clin Infect Dis 1988; 26: 314-322.

2. Stothard DR, Boguslawski G, Jones RB. Phylogenetic analysis of the Chlamydia trachomatis major protein and examination of potential pathogenic determinants. Infect Immun 1998; 66: 3618-3625.

3. Frost EH, Deslandes S, Veilleux S, et al. Typing Chlamydia trachomatis by detection of restriction fragment length polymorphism in the gene encoding the major outer membrane protein. J Infect Dis 1991; 163:1103-1107.

4. Sayada C, Denamur E, Orfila J, et al. Rapid genotyping of the Chlamydia trachomatis major outer membrane protein by the polymerase chain reaction. FEMS Microbiol Lett 1991; 67:73-78.

5. Rodriguez P, de Barbeyrac B, Persson K, et al. Evaluation of molecular typing for epidemiological study of Chlamydia trachomatis genital infections. J Clin Microbiol $1993 ; 31: 2238-2240$.

6. Ngandjio A, Clerc M, Fonkoua MC, et al. Restrictive endonuclease patterns of the omp1 gene of reference Chlamydia trachomatis strains and characterization of isolates from Cameroonian students. J Med Microbiol 2004; 53:47-50

7. Dean D, Patton M, Stephens RS. Direct sequence evaluation of the major outer membrane protein gene variant regions of Chlamydia trachomatis subtypes D, I, and L2. Infect Immun 1991; 59:1579-1582. 
8. Sayada C, Vretou E, Orfial J, et al. Heterogeneity within the first constant segment of the major outer membrane protein gene in Chlamydia trachomatis serovar D/Da distinguishes 2 lineages. C R Acad Sci III 1995; 318:943-949.

9. Millman K, Black CM, Johnson RE, et al. population-based genetic and evolutionary analysis of Chlamydia trachomatis urogenital strain variation in the United States. $\mathbf{J}$ Bacteriol 2004; 186:2457-2465.

10. Hsu MC, Tsai PY, Chen KT, et al. Genotyping of Chlamydia trachomatis from clinical specimens in Taiwan. J Med Microbiol 2006; 55:301-308.

11. Sturm-Ramirez K, Brumblay H, Diop K, et al. Molecular epidemiology of genital Chlamydia trachomatis infection in high risk women in Senegal, West Africa. J Clin Microbiol 2000; 338:2138-2145.

12. Lan J, Ossewarde JM, Walboomers JM, et al. Improved PCR sensitivity for direct genotyping of Chlamydia trachomatis serovars by using a nested PCR. J Clin Microbiol 1994; 32:528-530.

13. de Barbeyrac B, Geniaux M, Hocke C, et al. Detection of Chlamydia trachomatis in symptomatic and asymptomatic populations with urogenital specimens by AMP CT (Gen-Probe Incorporated) compared to other commercially available amplification assays. Diagn Microbiol Infect Dis 2000; 37:181-185.

14. Bianchi A, Scieux C, Brunat N, et al. An evaluation of the polymerase chain reaction amplicor Chlamydia trachomatis in male urine and female urogenital specimens. Sex Transm Dis 1994; 21:196-200.

15. Dowe G, Smikle M, King SD, et al. High prevalence of genital Chlamydia trachomatis infection in women presenting in different clinical settings in Jamaica: implications for control strategy. Sex Transm Infect 1999; 75:412-416. 
16. Rampersad J, Wang X, Gayadeen, et al. In-house polymerase chain reaction for affordable and sustainable Chlamydia trachomatis detection in Trinidad and Tobago. Rev Panam Salud Publica 2007; 22:317-322.

17. Adams OP, Carter AO, Prussia P. Risk behaviour, healthcare access and prevalence of infection with Chlamydia trachomatis and Neisseria gonorrhoeae in a populationbased sample of adults in Barbados. Sex Transm Infect 2008; 84:192-194.

18. Chout RT, Vaton S, Duval-Violton D, et al. Screening for Chlamydia trachomatis infection in pregnant women in Martinique. Sex Transm Dis 1995; 22 :221-227.

19. Asin JD, Nahorst RR, Thijs CT, et al. Routine testing for Chlamydia trachomatis on Curacao, Netherlands Antilles. Am J Obstet Gynecol 1993; 169:375-378.

20. Gao X, Chen XS, Yin YP, et al. Distribution study of Chlamydia trachomatis serovars among high-risk women in China performed using PCR-restriction fragment length polymorphism genotyping. J Clin Microbiol 2007; 1885-1189.

21. Jurstrand M, Falk L, Fredlung H, et al. Characterization of Chlamydia trachomatis ompl genotypes among sexually transmitted disease patients in Sweden. J Clin Microbiol 2001; 39:3915-3919.

22. Lee G, Park J, Kim B, et al. OmpA genotyping of Chlamydia trachomatis from Korean female sex workers. J Infect 2006; 52:451-454.

23. de Barbeyrac B, Clerc M, Idrissi Y, et al. Typage et etude de sensibilité des souches de Chlamydia trachomatis isolées en France, 1999-2001. Bulletin Epidemiologique Hebdomadaire 2004; 40-41.

24. Wang SP, Grayston JT. Three new serovars of Chlamydia trachomatis: Da, Ia, and L2a. J Infect Dis 1991; 163:403-405.

25. Geisler WM, Suchland RJ, Stamm. Association of Chlamydia trachomatis serovar Ia 
infection with black race in a sexually transmitted diseases clinic patient in

$400 \quad$ Birmingham, Alabama. Sex Transm Dis 2006; 33:621-624.

401 26. Workowski KA, Suchland RJ, Pettinger MB, et al. Association of genital infection 402 with specific Chlamydia trachomatis serovars and race. J Infect Dis 1992; $403 \quad 166: 1445-1449$.

404 27. Takahashi S, Yamazaki T, Satoh K, et al. Longitudinal epidemiology of Chlamydia 405 trachomatis serovars in female patients in Japan. Jpn J Infect Dis 2007; 60:374-376.

406 28. Morré SA, Munk C, Persson K, et al. Comparison of three commercially available 407 peptide-based immunoglobulin $\mathrm{G} \quad(\mathrm{IgG})$ and $\operatorname{Ig} \mathrm{A}$ assays to 408 microimmunofluorescence assay for detection of Chlamydia trachomatis antibodies. $409 \quad$ J Clin Microbiol 2002; 40:584-587.

410 29. Rabenau HF, Kohler E, Peters M, et al. Low correlation of serology with detection 411 of Chlamydia trachomatis by ligase chain reaction and antigen EIA. Infection 2000; $412 \quad 28: 97-102$.

413 30. Clad A, Feidank HM, Kunze M, et al. Detection of seroconversion and persistence of $414 \quad$ Chlamydia trachomatis antibodies in five different serological tests. Eur J Clin $415 \quad$ Microbiol Infect Dis 2000; 19:932-937. 


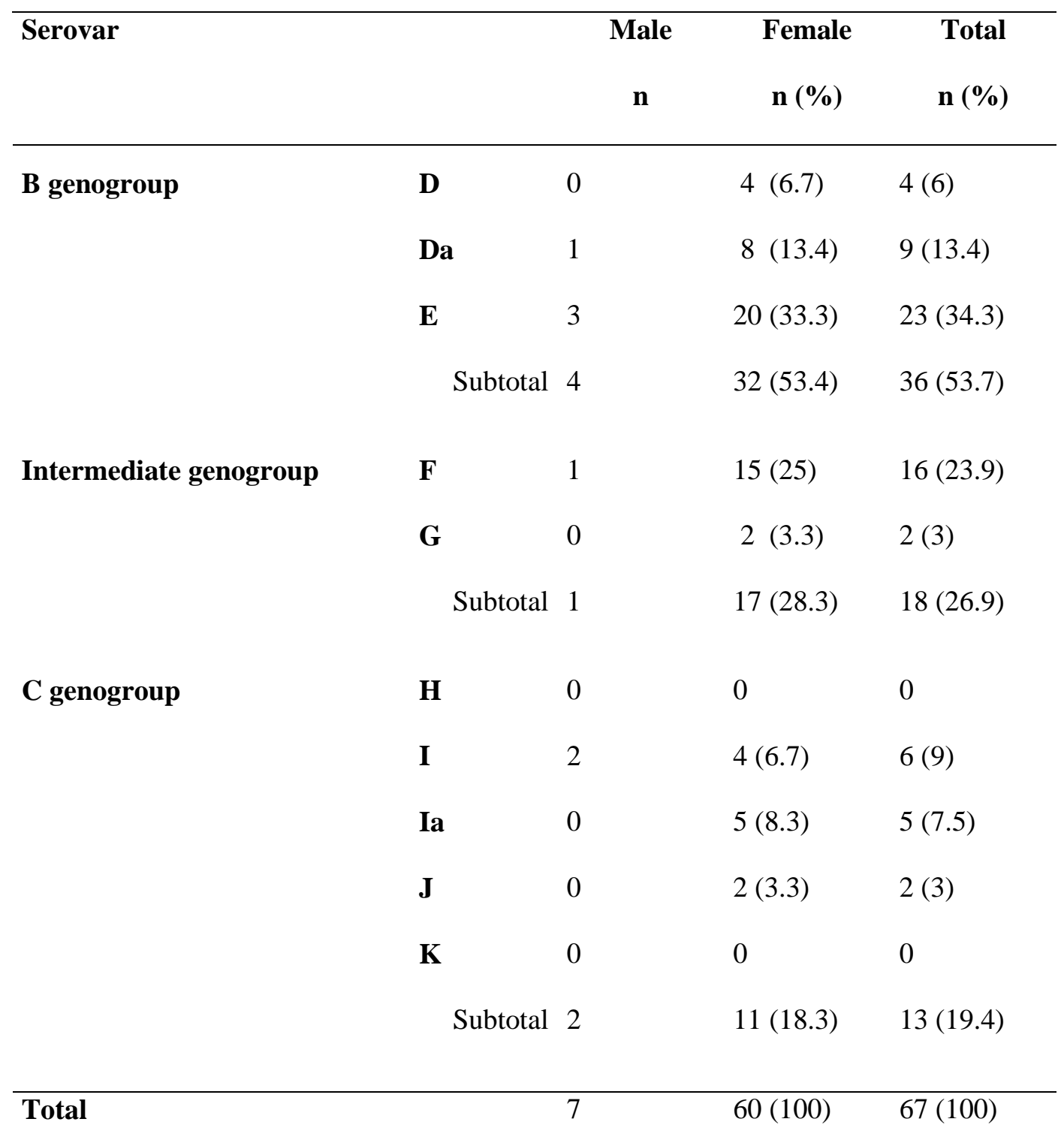

421 Table 1: Distribution of $C$. trachomatis genotypes in women and men, as 422 determined by omp1 nested PCR-based RFLP genotyping 


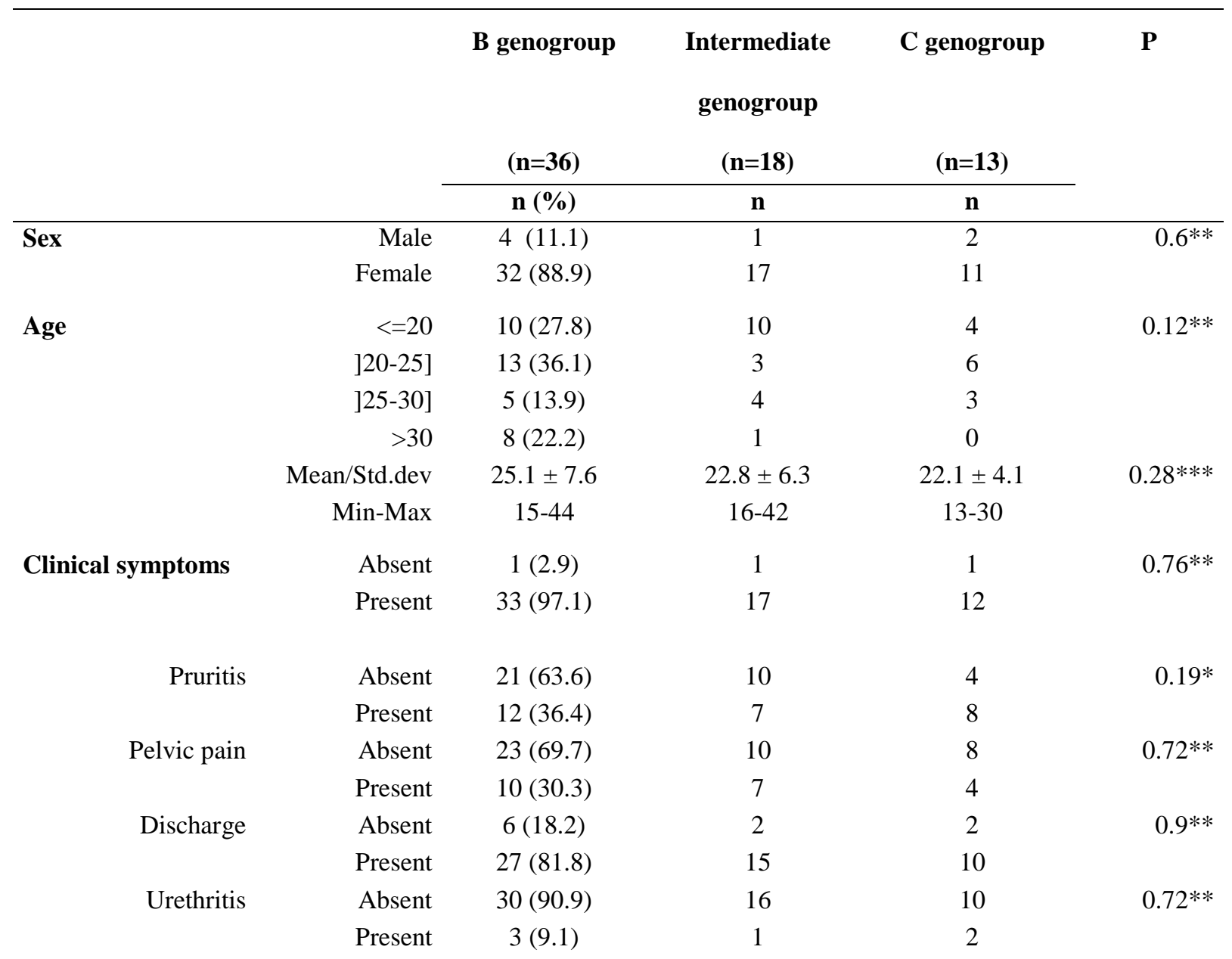

Genital infections

N. gonorrhoeae

Absent

35 (97.2)

18

$0.005^{* *}$

Present $1(2.8)$

0

Vaginosis

Absent 18 (50.0)

10

Present

$18(50.0)$

8

$0.64 *$

T. vaginalis

Absent $\quad 34$ (94.4)

18

Present

2 (5.6)

0

$0.58^{* *}$

Candida sp.

Absent $\quad 34$ (94.4)

17

Present 2 (5.6)

1

$1 * *$

HIV

Absent $\quad 30(88.2)$

18

$0.23 * *$

Present 4 (11.8)

0

13

0

$425 *$ Chi-squared test, $* *$ Fisher's exact test, $* * *$ Analysis of variance test

426 Table 2: Clinical and laboratory data as a function of $C$. trachomatis genogroup 


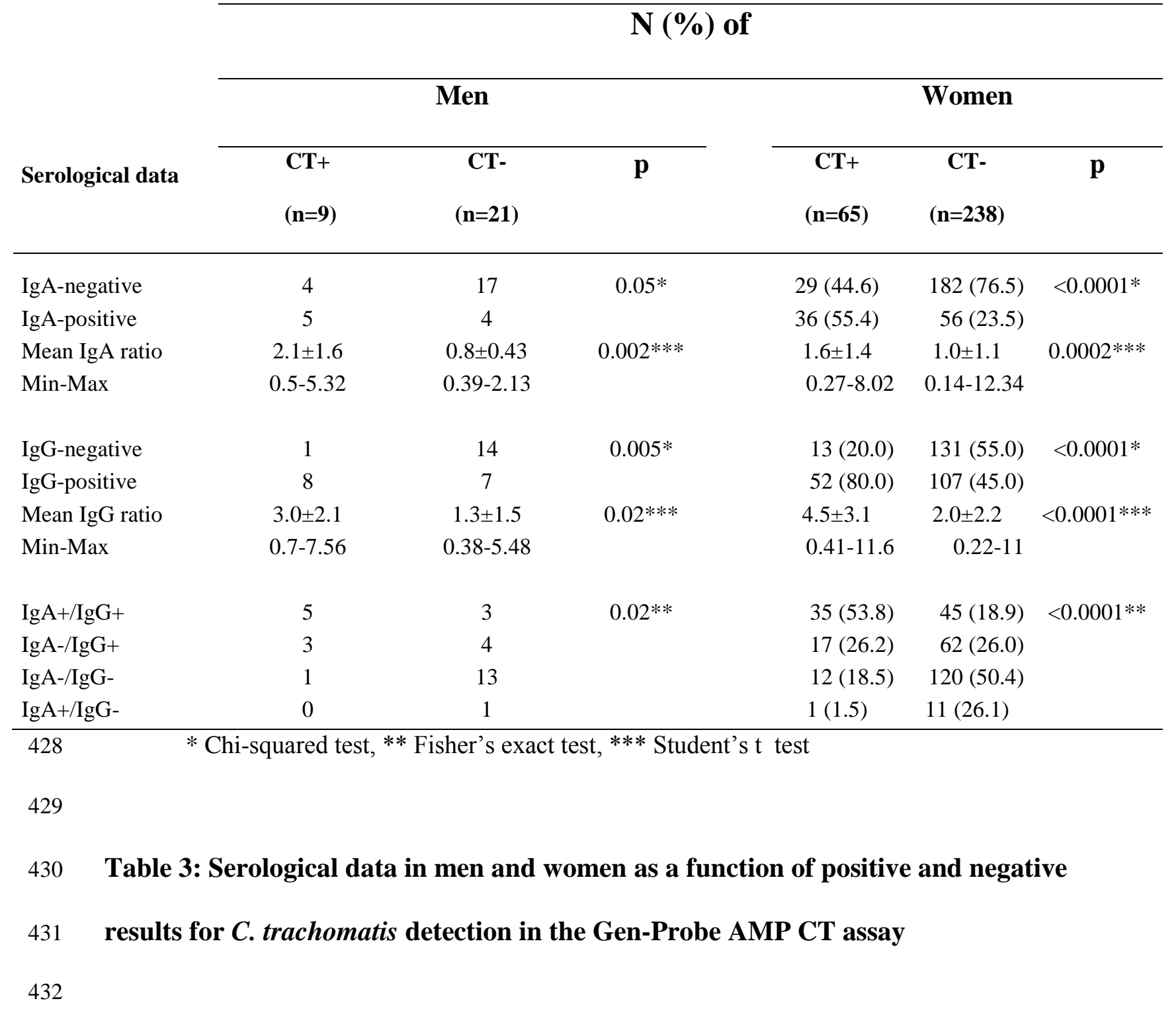




\begin{tabular}{|c|c|c|c|c|}
\hline & $\begin{array}{c}\text { B genogroup } \\
(\mathbf{n}=\mathbf{2 6})\end{array}$ & $\begin{array}{l}\text { Intermediate genogroup } \\
\qquad(\mathrm{n}=10)\end{array}$ & $\begin{array}{c}\text { C genogroup } \\
(\mathbf{n}=10)\end{array}$ & $\mathbf{P}$ \\
\hline Serological data & $\mathbf{n}$ & $\mathbf{n}$ & $\mathbf{n}$ & \\
\hline IgA-negative & 10 & 3 & 7 & $0.15^{*}$ \\
\hline IgA-positive & 16 & 7 & 3 & \\
\hline Mean IgA ratio & $1.44 \pm 0.93$ & $1.6 \pm 0.74$ & $1.87 \pm 2.47$ & $0.70^{* *}$ \\
\hline Min-Max & $0.27-3.45$ & $0.72-3.07$ & $0.34-8.02$ & \\
\hline IgG-negative & 2 & 0 & 6 & $0.001 *$ \\
\hline IgG-positive & 24 & 10 & 4 & \\
\hline Mean IgG ratio & $5.5 \pm 2.9$ & $6.5 \pm 3.8$ & $2.3 \pm 2.6$ & $0.008 * *$ \\
\hline Min-Max & $0.74-10.46$ & $1.1-11.6$ & $0.41-7.39$ & \\
\hline $\operatorname{IgA}+/ \operatorname{IgG}+$ & 16 & 7 & 3 & $0.007^{*}$ \\
\hline IgA-/IgG+ & 8 & 3 & 1 & \\
\hline IgA-/IgG- & 2 & 0 & 6 & \\
\hline
\end{tabular}

* Fisher's exact test, **Analysis of variance

435

436 Table 4: Serological data as a function of $C$. trachomatis genogroup

437 